\title{
The Effects of Visual Displays of Furniture Product Photos Through the Social Networking Site, Instagram on Consume Perception
}

\section{Pengaruh Tampilan Visual Foto Produk Furnitur Melalui Situs Jejaring Sosial Instagram Terhadap Persepsi Konsumen}

\author{
Dini Cinda Kirana*, Achmad Syarief, Dona Saphiranti \\ Universitas Pembangunan Jaya, Banten 15413, INDONESIA \\ *Corresponding author email: cindaga@gmail.com \\ Published: 7 September 2018
}

\begin{abstract}
At present, the growth of Instagram as an online site is phenomenal, because of the shift from its original function as a social communication medium into a marketing platform. Furniture products used to be only available for in-store purchase, can now be easily purchased online. The present study attempted to discover the level of influence and effectiveness of the visual appearance of the furniture products photos through the social networking site, Instagram on consumer perceptions, which is measured using the EPIC (Empathy, Persuasion, Impact and Communication) model. The purpose of the study was to identify the effectiveness of the visual display of furniture product photos on the Instagram social networking site on consumer's perceptions, and to map the use of the ideal visual display of furniture product photos for online product marketing purposes. The research used comparative analytical methods on photos of furniture products from six accounts of small creative economy entrepreneurs of similar products that are advertised through the social networking site, Instagram. The data of this study are limited in the scope of visual perception of furniture product photos uploaded through the social networking site, Instagram on consumer perceptions. The results showed that the visual display in the form of photos of furniture products through the social networking site, Instagram had an effective result on consumer perceptions. The visual display is declared effective as a media for promoting furniture products through the social networking site, Instagram based on the four dimensions of EPIC. The dimensions of Empathy and Impact are the most dominant aspects. The visual display mapping used as an advertising photo is not only influenced by the Empathy dimension and the Impact dimension, but also dominantly influenced by the associated design principles, namely, Unity and Domination. Both dimensions have a significant correlation value compared to other dimensions.
\end{abstract}

Keywords: Furniture Marketing, Instagram, Consumer Perception, EPIC Model, Design Principles

\begin{abstract}
ABSTRAK
Pada masa kini, perkembangan Instagram sebagai situs online sangat fenomenal, yang berakibat pada bergesernya fungsi semula sebagai media komunikasi sosial kemudian merambah menjadi media pemasaran. Produk furnitur yang semula harus didapatkan dengan cara membeli langsung ke toko, sekarang dapat dengan mudah dibeli secara online. Dalam penelitian ini akan dikaji seberapa besar pengaruh dan keefektifan tampilan visual dari foto produk furnitur melalui situs jejaring sosial Instagram terhadap persepsi konsumen, yang diukur dengan menggunakan model EPIC (Empathy, Persuasion, Impact dan Communication). Tujuan penelitian adalah untuk mengidentifikasi keefektifan tampilan visual foto produk furnitur pada situs jejaring sosial Instagram terhadap persepsi konsumen, dan memetakan penggunaan tampilan visual foto produk furnitur yang ideal untuk upaya pemasaran produk secara online. Penelitian menggunakan metode komparatif analitis terhadap foto produk furnitur dari 6 akun pengusaha kecil ekonomi kreatif produk sejenis yang dipasarkan melalui situs jejaring sosial Instagram. Data penelitian ini terbatas dalam lingkup persepsi visual dari foto produk furnitur yang diunggah melalui situs jejaring sosial Instagram terhadap persepsi konsumen. Hasil
\end{abstract}


penelitian menunjukkan bahwa tampilan visual dalam bentukfoto produk furnitur melalui situs jejaring sosial Instagram berpengaruh efektif terhadap persepsi konsumen. Tampilan visual dinyatakan efektif sebagai media promosi produk furnitur melalui situs jejaring sosial Instagram berdasarkan 4 dimensi EPIC. Adapun dimensi Empathy dan Impact menjadi aspek yang paling dominan. Pemetaan tampilan visual yang digunakan sebagai foto promosi selain dipengaruhi oleh dimensi Empathy dan dimensi Impact, juga dipengaruhi secara dominan oleh prinsip desain terkait, yaitu; Unity dan Domination. Kedua dimensi mempunyai nilai korelasi signifikan dibanding dimensi lainnya.

Kata kunci: Pemasaran Furnitur, Instagram, Persepsi Konsumen, Model EPIC, Prinsip Desain.

eISSN: 2550-214X (C) 2018. The Authors. Published for Idealogy Journal of Arts and Social Science by UiTM Press. This is an Open Access article distributed under the terms of the Creative Commons Attribution-NonCommercial-NoDerivatives License (http://creativecommons.org/licenses/by-nc-nd/4.0/), which permits non-commercial re-use, distribution, and reproduction in any medium, provided the original work is properly cited, and is not altered, transformed, or built upon in any way.

\section{PENDAHULUAN}

Pemasaran digital mulai menjadi tren di era internet ini. Para pengusaha baik itu perorangan atau perusahaan mulai menjadikan media digital sebagai media promosi dan pemasaran yang baru. Pada dasarnya media situs jejaring sosial telah mengubah bagaimana konsumen berinteraksi dan bagaimana perusahaan memasarkan produk, meskipun di Indonesia trennya masih tergolong kecil, tapi pertumbuhannya cukup pesat. Adanya situs jejaring sosial ini dijadikan peluang usaha yang baik untuk memasarkan atau mempromosikan produk yang akan dijual. Banyak kelebihan yang dapat diambil dari pemasaran lewat situs jejaring sosial ini diantaranya sebagai sarana berkomunikasi dengan konsumen, sebagai media berkolaborasi apabila adanya ketidakpuasan konsumen, sebagai media promosi dan membangun merek dagang. Pelaku bisnis mengaku lebih mudah memasarkan produknya melalui situs jejaring sosial karena sasaran pertama bisnis ini adalah orang yang dikenal, sehingga mudah untuk melakukan komunikasi.

Maraknya pertumbuhan pengusaha kecil ekonomi kreatif atau usaha kecil menengah (UKM) di kalangan anak muda khususnya di kota-kota besar Indonesia, seperti Jakarta, Bandung dan Jogjakarta, seiring dengan pemasaran digital di era internet ini merupakan fenomena tersendiri. Para UKM ini meramu kreativitas mereka dalam strategi pemasaran online melalui situs jejaring sosial, yaitu dengan cara saling bersaing mengunggah foto-foto produk mereka yang sudah dikonsep sedemikian rupa sehingga dapat menarik para pengguna internet atau calon konsumen mereka.

Fenomena memanfaatkan situs jejaring sosial seperti Instagram dalam menjalankan bisnis dan mendatangkan keuntungan secara ekonomis ini sangat menarik, berkaitan dengan kenyataan ternyata Instagram merupakan situs jejaring sosial yang multifungsi. Pada penelitian-penelitian terdahulu sudah banyak yang meniliti tentang pemasaran melalui situs jejaring sosial juga, seperti Facebook dan Twitter. Pemasaran melalui situs jejaring sosial Instagram dan khususnya memasarkan produk furnitur belum pernah dikaji dan dianalisis, sehingga penulis menjadikan strategi pemasaran baru ini menjadi suatu dasar pemikiran untuk meneliti bagaimana pengaruh tampilan visual berupa foto produk furnitur melalui situs jejaring sosial Instagram ini efektif terkait dengan persepsi konsumen. Untuk mengukur keefektifannya terkait dengan persepsi konsumen, maka penulis menggunakan model EPIC. Model EPIC (Empathy, Persuasion, Impact dan Communication) ini dikembangkan oleh salah satu perusahaan peneliti pemasaran terkemuka di dunia, yaitu A.C.Nielsen sebagai alat analisis untuk mengukur efektivitas iklan (Durianto,2003).

Pemasaran produk furnitur melalui media online Instagram ini merupakan media pemasaran yang 'baru', dalam artian tidak konvensional karena menyebabkan timbulnya kendala baru, yaitu masyarakat tidak dapat berinteraksi langsung dengan produk tersebut. Pada umumnya apabila membeli produk furnitur, masyarakat biasanya berinteraksi langsung, produk furnitur tersebut harus bisa dipegang, diraba, dicoba atau bahkan diduduki baru kemudian dibeli. 
The Effects of Visual Displays of Furniture Product Photos Through the Social Networking Site, Instagram on Consume Perception

Pengaruh Tampilan Visual Foto Produk Furnitur Melalui Situs Jejaring Sosial Instagram Terhadap Persepsi

Konsumen

Dari permasalahan yang dijabarkan di atas, tersusun beberapa pertanyaan masalah yang mencakup intisari semua masalah kajian fenomena pengaruh dan keefektifan tampilan visual foto produk furnitur melalui situs jejaring sosial Instagram terhadap persepsi konsumen.

Pertanyaan penelitian adalah sebagai berikut:

1. Sejauh mana tampilan visual dalam bentuk foto produk furnitur melalui situs jejaring sosial Instagram, efektif mempengaruhi persepsi konsumen?

2. Seperti apakah pemetaan penggunaan tampilan visual foto produk furnitur yang ideal sebagai upaya pemasarannya melalui situs jejaring sosial Instagram?

Obyek yang diteliti terbatas pada tampilan visual foto produk furnitur dari 6 pengusaha kecil ekonomi kreatif atau usaha kecil menengah (UKM) terpilih di Indonesia yang menjual produknya melalui situs jejaring sosial Instagram, yaitu; Hvnter Home (Bandung), Jakarta Vintage (Jakarta), Jovinco Jogja (Jogjakarta), Karsa Design (Jakarta), Kekayuan (Jakarta) dan Unk1 347 (Bandung). Mereka terpilih dari hasil pemantauan penulis atas dasar pengelompokan kategori berdasarkan tipe visualisasi dan tipe produknya yang sejenis, yaitu produk kursi sofa yang diletakan pada satu ruangan interior full set.

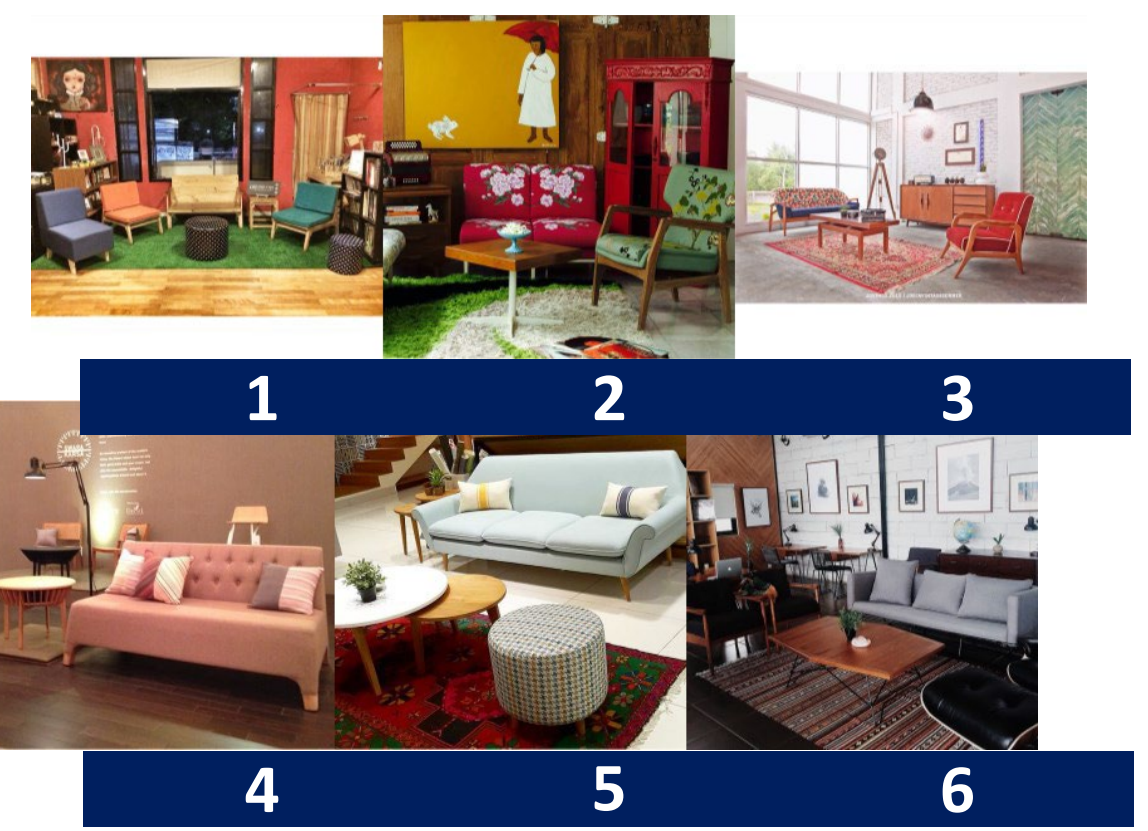

Gambar 1. Tampilan Visual Foto Produk Furnitur dari 6 Akun UKM Ekonomi Kreatif melalui Situs Jejaring Sosial Instagram (sumber : http://instagram.com/)

\section{METODE PENELITIAN}

Penelitian ini menggunakan metode survei dengan kuesioner sebagai sumber data utama. Metode survei dipakai untuk mendapatkan data faktual tentang pengaruh tampilan visual terhadap persepsi konsumen.

\subsection{Kuesioner Tahap Awal}

Jenis sampling merupakan purposive sampling. Untuk pengambilan sampel, subyek yang ingin dijadikan responden pada penelitian ini diambil dari kelompok usia antara usia dibawah 25 tahun, dengan asumsi rata-rata responden masih lajang dan usia diatas 25 tahun dengan asumsi rata-rata responden sudah menikah Kategori profil responden pun mengelompokan status kepemilikan rumah respoden menjadi; rumah pribadi, rumah orang tua, rumah sewa/kost. Pengelompokan usia dan status kepemilikan rumah ini keterkaitannya dengan tampilan visual produk furnitur yang ditawarkan dilihat dari aspek kebutuhan, misalnya responden yang belum menikah dan masih tinggal dengan orang tua 
tidak akan terlalu butuh untuk membeli produk furnitur baru, responden belum menikah tapi sudah menyewa rumah mungkin butuh untuk membeli produk furnitur baru, atau responden yang sudah menikah tapi masih tinggal bersama orang tua, tentunya masih berpikir untuk membeli produk furnitur baru, dan seterusnya. Semua responden wajib memiliki akun pada situs jejaring sosial Instagram sebagai pengguna aktif, dengan harapan penelitian menjadi lebih objektif.

Peneliti membuat pernyataan kuesioner menggunakan skala Likert berdasarkan dimensi yang terdapat pada model $E P I C$, yaitu empati, persuasi, dampak dan komunikasi. Pernyataan yang digunakan pada kuesioner yang menyangkut dimensi model EPIC ini, adalah sebagai berikut :

- Empathy, suka atau tidaknya responden terhadap tampilan visual produk furnitur yang ditampilkan.

- Persuasion, tertarik ingin membeli atau tidaknya responden terhadap tampilan visual produk furnitur yang ditampilkan.

- Impact, mengetahui fungsi produk atau tidaknya responden terhadap tampilan visual produk furnitur yang ditampilkan.

- Communication, mengetahui informasi/pesan yang ingin disampaikan atau tidaknya responden terhadap tampilan visual produk furnitur yang ditampilkan.

Pertanyaan-pertanyaan dalam kuesioner berkaitan dengan dimensi-dimensi yang terdapat pada model EPIC (Empathy, Persuasion, Impact dan Communication), dengan indikator sebagai berikut,

Tabel 1: Indikator Model EPIC (Empathy, Persuasion, Impact, Communication)

\begin{tabular}{cll}
\hline No & \multicolumn{1}{c}{ Dimensi } & \multicolumn{1}{c}{ Indikator } \\
\hline 1 & EMPATI (Empathy) & emosi, perasaan khusus, suasana hati, dan evaluasi \\
2 & PERSUASI (Persuasion) & perilaku dan opini, emosi, keterlibatan, dan pendirian \\
3 & DAMPAK (Impact) & fungsi dan kegunaan produk, kreativitas visual \\
4 & KOMUNIKASI (Communication) & pemahaman pembaca dan kekuatan pesan \\
\hline
\end{tabular}

Sumber: Durianto,2003

Indikator dari dimensi dalam proses penelitian ini menggunakan skala Likert, yaitu skala yang memberikan skor dari 0-4, dari sangat tidak setuju hingga sangat setuju untuk mengetahui derajat responden terhadap serangkaian pertanyaan yang terdapat dalam kuesioner. Data dari kuesioner akan dikonversikan menjadi angka kemudian dihitung nilai rata-ratanya. Nilai rata-rata tersebut dapat menggambarkan seberapa jauh tingkat efektivitas pengaruh tampilan visual foto produk furnitur terhadap persepsi konsumen melalui grafik dan diagram diamond.

\subsection{Kuesioner Tahap Akhir}

Kuesioner tahap akhir ini berupa daftar pertanyaan masih seputar masalah kajian yang berguna untuk menjawab rumusan masalah terkait dengan teori prinsip desain. Kuesioner akan dibagikan kepada responden yang terdiri dari para ahli di bidang visual, baik itu akademisi maupun praktisi dengan pengalaman masing- masing 5 tahun di bidangnya.

Pertanyaan-pertanyaan dalam kuesioner tahap akhir ini berkaitan dengan dimensi-dimensi yang terdapat pada teori prinsip desain, yaitu; kesatuan (unity), keseimbangan (balance), proporsi (proportion), irama (rhythm), dan dominasi (domination). Pertanyaan kuesioner tahap 3 berdasarkan indikator sebagai berikut: 
Tabel 2: Indikator Teori Prinsip Desain

\begin{tabular}{cll}
\hline No & \multicolumn{1}{c}{ Dimensi } & \multicolumn{1}{c}{ Indikator } \\
\hline 1 & Kesatuan (Unity) & beberapa unsur rupa dalam tampilan visual mempunyai \\
& & hubungan \\
2 & Keseimbangan (Balance) & susunan terlihat seimbang antara satu sama lain yang terkait \\
3 & Proporsi (Proportion) & keselarasan, setara dengan keseimbangan \\
4 & Irama (Rhythm) & gerak yang teratur dan terus menerus \\
5 & Dominasi (Domination) & elemen-elemen visual sebagai penarik dan pusat perhatian. \\
\hline
\end{tabular}

Indikator dari dimensi dalam proses penelitian ini menggunakan skala Likert, yaitu skala yang memberikan skor dari 0-4, dari sangat tidak setuju hingga sangat setuju untuk mengetahui derajat responden terhadap serangkaian pertanyaan yang terdapat dalam kuesioner.

\section{HASIL DAN PEMBAHASAN KUESIONER TAHAP AWAL}

Tabel 3: Variabel Pernyataan Kuesioner Tahap Awal berdasarkan Dimensi Model EPIC

\begin{tabular}{|c|c|c|}
\hline No & Dimensi & Pernyataan \\
\hline 1 & Empathy 1 (E1) & Tampilan visual dari foto produk furnitur kursi sofa ini bagus. \\
\hline 2 & Empathy 2 (E2) & Saya suka tampilan visual dari foto produk furnitur kursi sofa ini. \\
\hline 3 & Persuasion 1 (P1) & saya tertarik melihat tampilan visual produk furnitur kursi sofa tersebut. \\
\hline 4 & Persuasion 2 (P2) & $\begin{array}{l}\text { Saya ingin membeli setelah melihat tampilan visual dari foto produk } \\
\text { furnitur } \\
\text { kursi sofa ini. }\end{array}$ \\
\hline 5 & Impact 1 (I1) & $\begin{array}{l}\text { Saya mengetahui fungsi dari produk furnitur kursi sofa ini setelah melihat } \\
\text { tampilan visual fotonya. }\end{array}$ \\
\hline 6 & Impact 2 (I2) & $\begin{array}{l}\text { Tampilan visual foto produk furnitur kursi sofa ini lebih kreatif dibanding } \\
\text { tampilan visual foto lain. }\end{array}$ \\
\hline 7 & $\begin{array}{l}\text { Communication } 1 \\
\text { (C1) }\end{array}$ & $\begin{array}{l}\text { Tampilan visual foto produk furnitur kursi sofa ini informasinya lebih jelas } \\
\text { dibanding tampilan visual foto lain. }\end{array}$ \\
\hline 8 & $\begin{array}{l}\text { Communication } 2 \\
\text { (C2) }\end{array}$ & $\begin{array}{l}\text { Tampilan visual foto ini lebih mampu mengkomunikasikan pesan yang } \\
\text { ingin disampaikan dibanding tampilan visual foto lain }\end{array}$ \\
\hline
\end{tabular}

Setiap jawaban responden dari pernyataan diberikan bobot. Pada kuesioner bagian kedua, pertanyaan menggunakan rentang skala Likert dari Sangat Tidak Setuju (STS) sampai dengan Sangat Setuju (ST), dan nilainya disusun berdasarkan nilai 0 sampai dengan 4. Kemudian nilai tersebut dipetakan ke dalam Model EPIC menggunakan rentang skala dari Sangat Tidak Efektif (STE) menjadi Sangat Efektif (SE).

Grafik berbentuk diagram diamond dari hasil analisis pengaruh tampilan visual foto produk furnitur melalui situs jejaring sosial Instagram terhadap persepsi konsumen dilihat dari nilai keefektifannya adalah sebagai berikut, 


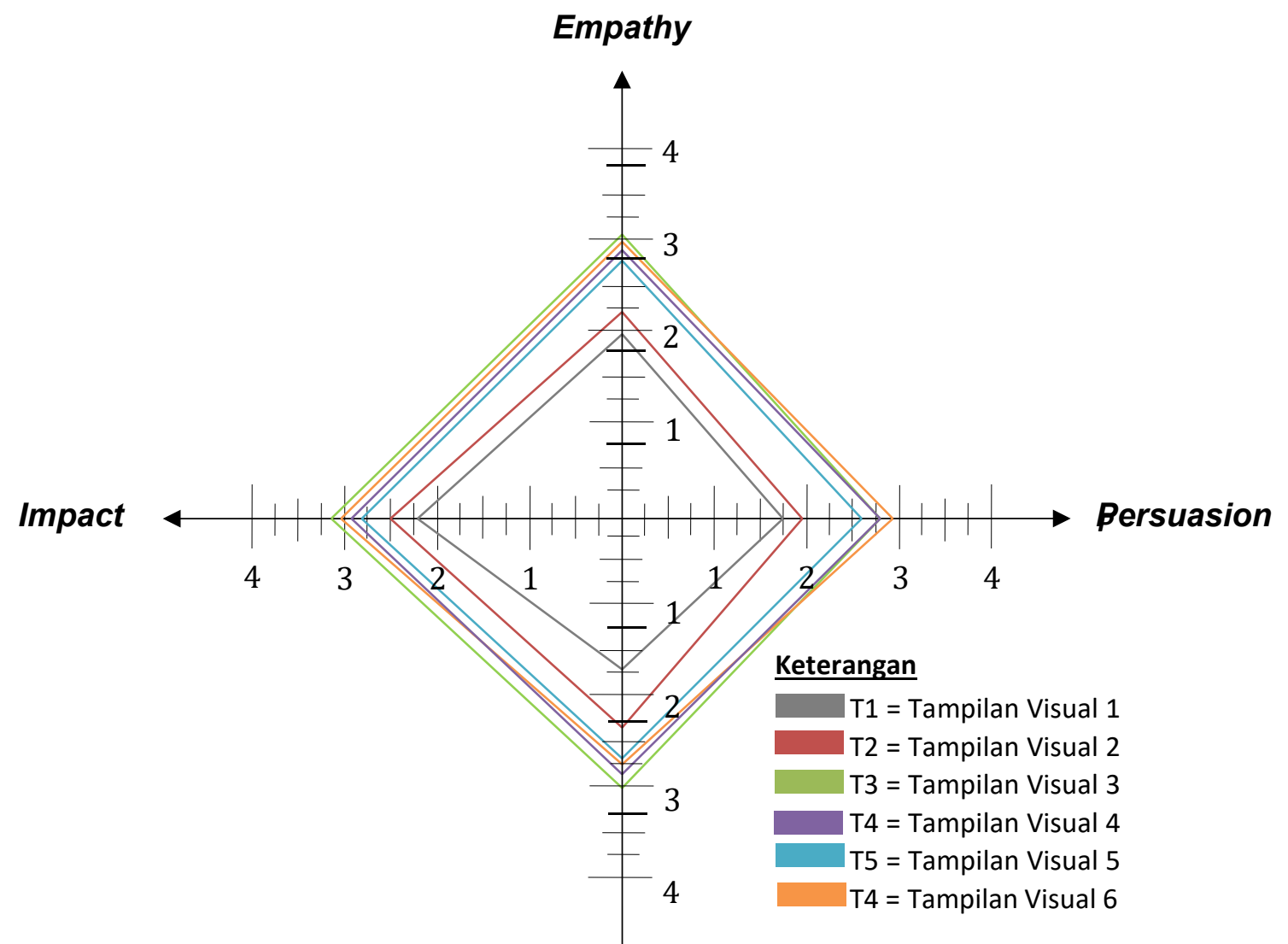

\section{Communication}

\begin{tabular}{lcccccc}
\hline \multicolumn{1}{c}{ Dimensi } & \multicolumn{9}{c}{ Tampilan Visual } \\
& T1 & T2 & T3 & T4 & T5 & T6 \\
\hline Empathy & 2.02 & 2.24 & $\mathbf{3 . 1 7}$ & 2.98 & 2.80 & 3.08 \\
Persuasion & 1.75 & 1.98 & 2.76 & 2.76 & 2.67 & $\mathbf{2 . 8 5}$ \\
Impact & 2.21 & 2.50 & $\mathbf{3 . 1 0}$ & 2.93 & 2.85 & 3.04 \\
Communication & 1.66 & 2.24 & $\mathbf{2 . 8 9}$ & 2.75 & 2.63 & 2.73 \\
\hline
\end{tabular}

Gambar 2: Grafik Diagram Diamond Model EPIC

Hasil analisis yang didapat melalui diagram diamond menyatakan bahwa Tampilan Visual 3 lebih efektif dilihat hampir dari semua sisi dimensi Model EPIC dibanding tampilan visual foto produk lainnya, yaitu pada dimensi empati, dampak dan komunikasi. Sedangkan untuk dimensi persuasi, nilai keefektifanya terlihat pada Tampilan Visual 6. Maka asumsi pertama dan kedua dari penelitian ini yang menyatakan bahwa pemetaan penggunaan tampilan visual foto produk furnitur sebagai upaya pemasarannya dan pengidentifikasian keefektifan tampilan visual foto produk furnitur tersebut berkaitan dengan respon konsumen berdasarkan dimensi empati, persuasi, dampak dan komunikasi dapat dibuktikan dari perolehan data hasil kuesioner pada Tampilan Visual 3 dan 6 yang sekaligus menjawab kedua pertanyaan penelitian ini. 
The Effects of Visual Displays of Furniture Product Photos Through the Social Networking Site, Instagram on

Consume Perception

Pengaruh Tampilan Visual Foto Produk Furnitur Melalui Situs Jejaring Sosial Instagram Terhadap Persepsi

\section{HASIL DAN PEMBAHASAN KUESIONER TAHAP AKHIR}

Tabel 4: Variabel Pertanyaan Kuesioner Tahap Akhir berdasarkan Teori Prinsip Desain

\begin{tabular}{|c|c|c|}
\hline No & Dimensi & Pertanyaan \\
\hline 1 & Kesatuan (Unity) & Menurut anda tampilan visual 1 ini mempunyai Kesatuan (Unity)? \\
\hline 2 & $\begin{array}{l}\text { Keseimbangan } \\
\text { (Balance) }\end{array}$ & Menurut anda tampilan visual 1 ini mempunyai Keseimbangan (Balance)? \\
\hline 3 & Proporsi (Proportion) & $\begin{array}{l}\text { Menurut anda tampilan visual } 1 \text { ini mempunyai Proporsi (Proportion) } \\
\text { yang } \\
\text { baik dan mempunyai keselarasan yang setara dengan keseimbangan? }\end{array}$ \\
\hline 4 & Irama $($ Rhythm $)$ & $\begin{array}{l}\text { Menurut anda tampilan visual } 1 \text { ini mempunyai Irama (Rhythm) yang } \\
\text { baik? }\end{array}$ \\
\hline 5 & $\begin{array}{l}\text { Dominasi } \\
\text { (Domination) }\end{array}$ & $\begin{array}{l}\text { Menurut anda tampilan visual } 1 \text { ini mempunyai Dominasi (Domination) } \\
\text { sebagai pusat perhatian? }\end{array}$ \\
\hline
\end{tabular}

Setiap jawaban responden dari pertanyaan diberikan bobot nilai. Pengujian validitas dilakukan dengan melakukan korelasi antara masing-masing skor indikator dengan total skor indikator.

Model korelasi Pearson dipakai untuk menguji hipotesis asosiatif. Berikut ini nilai dan makna pada uji signifikansi menggunakan korelasi Pearson:

Tabel 5: Makna Nilai Korelasi Model Pearson

\begin{tabular}{cc}
\hline Interval Koefisien & Tingkat Hubungan \\
\hline $0,00-0,199$ & Sangat Rendah \\
$0,20-0,399$ & Rendah \\
$0,40-0,599$ & Sedang \\
$0,60-0,799$ & Kuat \\
$0,80-1,000$ & Sangat Kuat \\
\hline
\end{tabular}


Correlations

\begin{tabular}{llrrrrr}
\hline & & Unity & Balance & Proportion & \multicolumn{2}{c}{ Rhythm Domination } \\
\hline & Pearson Correlation & -.390 & -.166 & -.720 & -.187 & -.060 \\
TP_1 & Sig. (2-tailed) & .445 & .753 & .106 & .723 & .910 \\
& N & 6 & 6 & 6 & 6 & 6 \\
& Pearson Correlation & .638 & .789 & .240 & .548 & .602 \\
TP_2 & Sig. (2-tailed) & .173 & .062 & .647 & .260 & .206 \\
& N & 6 & 6 & 6 & 6 & 6 \\
& Pearson Correlation & $.973^{* *}$ & $.855^{*}$ & .798 & .692 & $.865^{*}$ \\
TP_3 & Sig. (2-tailed) & .001 & .030 & .057 & .128 & .026 \\
& N & 6 & 6 & 6 & 6 & 6 \\
& Pearson Correlation & .647 & $.849^{*}$ & .664 & $.871^{*}$ & .737 \\
TP_4 & Sig. (2-tailed) & .165 & .033 & .151 & .024 & .095 \\
& N & 6 & 6 & 6 & 6 & 6 \\
& Pearson Correlation & .463 & .156 & .674 & .177 & .243 \\
TP_5 & Sig. (2-tailed) & .355 & .768 & .142 & .738 & .643 \\
& N & 6 & 6 & 6 & 6 & 6 \\
& Pearson Correlation & .580 & .504 & $.854^{*}$ & .634 & .598 \\
TP_6 & Sig. (2-tailed) & .228 & .308 & .031 & .177 & .210 \\
& N & 6 & 6 & 6 & 6 & 6 \\
\hline
\end{tabular}

**. Correlation is significant at the 0.01 level (2-tailed).

*. Correlation is significant at the 0.05 level (2-tailed).

TP_1 = Total Prinsip Desain pada Tampilan Visual 1

TP 2 = Total Prinsip Desain pada Tampilan Visual 2

TP 3 = Total Prinsip Desain pada Tampilan Visual 3

TP $4=$ Total Prinsip Desain pada Tampilan Visual 4

TP $5=$ Total Prinsip Desain pada Tampilan Visual 5

TP_6 = Total Prinsip Desain pada Tampilan Visual 6

\section{Gambar 3: Hasil Pengujian Korelasi Teori Prinsip Desain pada Tampilan Visual}

Nilai korelasi pada variabel Unity terhadap total nilai teori prinsip desain pada Tampilan Visual 3 mempunyai nilai tertinggi (0.973) dengan nilai signifikan yang tinggi yaitu diatas 0.01 . Diikuti oleh nilai variabel lainnya yang diurutkan dari variabel dengan korelasi nilai paling kuat, yaitu; nilai korelasi pada variabel Rhythm terhadap total nilai teori prinsip desain pada Tampilan Visual 4 (0.871), nilai korelasi pada variabel Domination terhadap total nilai teori prinsip desain pada Tampilan Visual 3 (0.865), nilai korelasi pada variabel Balance terhadap total nilai teori prinsip desain pada Tampilan Visual 3 (0.855), nilai korelasi pada variabel Proportion terhadap total nilai teori prinsip desain pada Tampilan Visual 6 (0.854), dan nilai korelasi pada variabel Balance terhadap total nilai teori prinsip desain pada Tampilan Visual 4 (0.849), kelima variabel ini mempunyai nilai signifikan yang rendah yaitu diatas 0.05 . 
The Effects of Visual Displays of Furniture Product Photos Through the Social Networking Site, Instagram on Consume Perception

Pengaruh Tampilan Visual Foto Produk Furnitur Melalui Situs Jejaring Sosial Instagram Terhadap Persepsi

\section{HASIL TEMUAN PENELITIAN}

Konsumen

Tampilan visual yang efektif untuk dijadikan sebagai media promosi produk furnitur melalui situs jejaring sosial dinilai dari keempat dimensi EPIC yang dinyatakan efektif berdasarkan hasil analisis. Didapatkan hasil perhitungan dari masing-masing variabel berturut-turut adalah sebagai berikut:

Tabel 6: Nilai Rata-Rata Model EPIC

\begin{tabular}{lccccccc}
\hline \multicolumn{1}{c}{ Dimensi } & \multicolumn{7}{c}{ Tampilan Visual } \\
& T1 & T2 & T3 & T4 & T5 & T6 \\
\hline Empathy & 2.02 & 2.24 & $\mathbf{3 . 1 7}$ & 2.98 & 2.80 & 3.08 \\
Persuasion & 1.75 & 1.98 & 2.76 & 2.76 & 2.67 & $\mathbf{2 . 8 5}$ \\
Impact & 2.21 & 2.50 & $\mathbf{3 . 1 0}$ & 2.93 & 2.85 & 3.04 \\
Communication & 1.66 & 2.24 & $\mathbf{2 . 8 9}$ & 2.75 & 2.63 & 2.73 \\
\hline
\end{tabular}

Nilai pada dimensi Empathy dan Impact menjadi yang paling dominan diantara dimensi lainnya. Para pemilik pengusaha kecil ekonomi kreatif atau usaha kecil menengah (UKM) dapat lebih menekankan pada peningkatan dan mempertahankan faktor dominan ini dalam upaya mempertahankan keefektifan tampilan visual foto produk yang ingin dipasarkan melalui situs jejaring sosial Instagram.

Tampilan visual yang mempunyai nilai keefektifan tertinggi dari tiap dimensi EPIC, adalah:

1. Tampilan Visual 3, mempunyai nilai keefektifan tertinggi pada dimensi;

Empathy, Impact, dan Communication.

2. Tampilan Visual 6, mempunyai nilai keefektifan tertinggi pada dimensi Persuasion.

T3

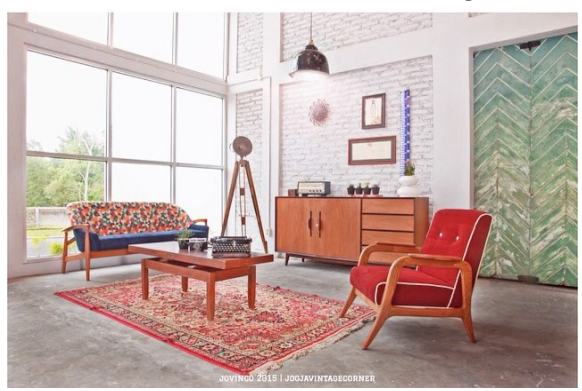

T6

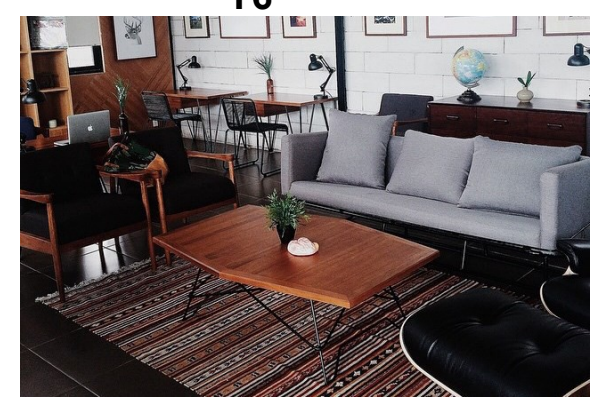

Gambar 4: Tampilan Visual yang Mempunyai Nilai Keefektifan Tinggi (sumber foto : http://instagram.com/)

Total nilai teori prinsip desain pada tampilan visual yang mempunyai nilai korelasi tertinggi untuk dijadikan media promosi produk melalui situs jejaring sosial dinilai dari lima dimensi pada teori prinsip desain.

Didapatkan dari hasil pengujian diurut berdasarkan nilai korelasi tertinggi yang signifikan, adalah sebagai berikut:

1. Tampilan Visual 3, mempunyai nilai korelasi tertinggi yang signifikan pada dimensi; Unity, Domination, dan Balance.

2. Tampilan Visual 4, mempunyai nilai korelasi tertinggi yang signifikan pada dimensi; Rhythm dan Balance.

3. Tampilan Visual 6, mempunyai nilai korelasi tertinggi yang signifikan pada dimensi Proportion. 


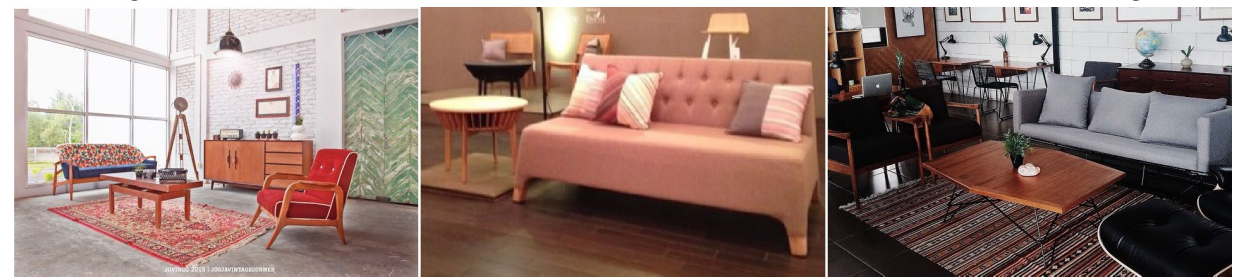

Gambar 5: Tampilan Visual yang Mempunyai Nilai Korelasi Signifikan (sumber foto: http://instagram.com/)

\section{KESIMPULAN}

Hasil analisis akhir yang dapat kita simpulkan, bahwa tampilan visual foto produk furnitur yang mumpunyai nilai efektif tertinggi terhadap persepsi konsumen berdasarkan kuesioner tahap 2 yang dihubungkan dengan tampilan visual yang mempunyai nilai korelasi yang signifikan berdasarkan teori prinsip desain menurut para ahli visual melalui kuesioner tahap 3, adalah:

1. Tampilan Visual 3

2. Tampilan Visual 6

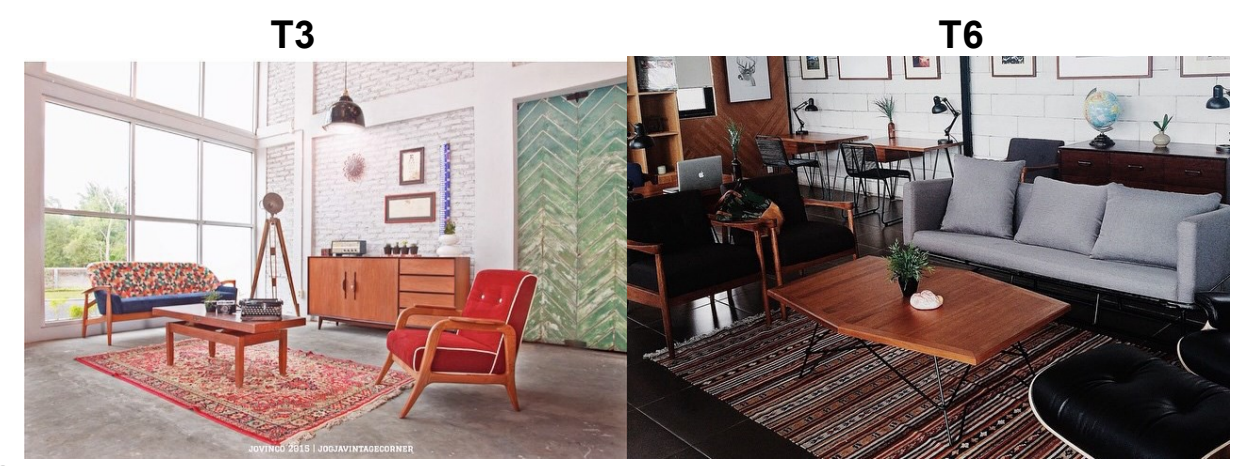

\section{Gambar 6: Tampilan Visual yang Ideal untuk Dipasarkan melalui Instagram (sumber foto: http://instagram.com/)}

Berdasarkan perolehan hasil data kuesioner, nilai keefektifannya muncul dilihat dalam 2 hal yaitu dalam dimensi Empathy (empati), yaitu apakah tampilan visual tersebut bagus atau tidak dan konsumen suka atau tidak terhadap tampilan visual tersebut. Dalam dimensi Impact (dampak), yaitu apakah tampilan visual itu lebih kreatif atau tidak dibandingkan tampilan visual lainnya, dan konsumen mengetahui atau tidaknya fungsi dari produk yang ditampilkan secara visual tersebut jika dibandingkan dengan tampilan visual lainnya. Tampilan visual yang akan digunakan sebagai media promosi produk furnitur melalui situs jejaring sosial Instagram harus sesuai berdasarkan dengan teori prinsip desain, dengan urutan hirarki sebagai berikut yaitu; Unity, Domination, Balance, Proportion, dan Rhythm (kesatuan, dominasi, keseimbangan, proporsi, dan irama) sehingga konsumen tertarik pada tampilan visual tersebut. 
The Effects of Visual Displays of Furniture Product Photos Through the Social Networking Site, Instagram on Consume Perception Pengaruh Tampilan Visual Foto Produk Furnitur Melalui Situs Jejaring Sosial Instagram Terhadap Persepsi Konsumen

Berikut adalah skema temuan tampilan visual yang paling efektif dan mempunyai nilai korelasi dengan signifikan tertinggi dari hasil analisis berdasarkan urutan hirarki dari dimensi EPIC dan dimensi pada teori prinsip desain:

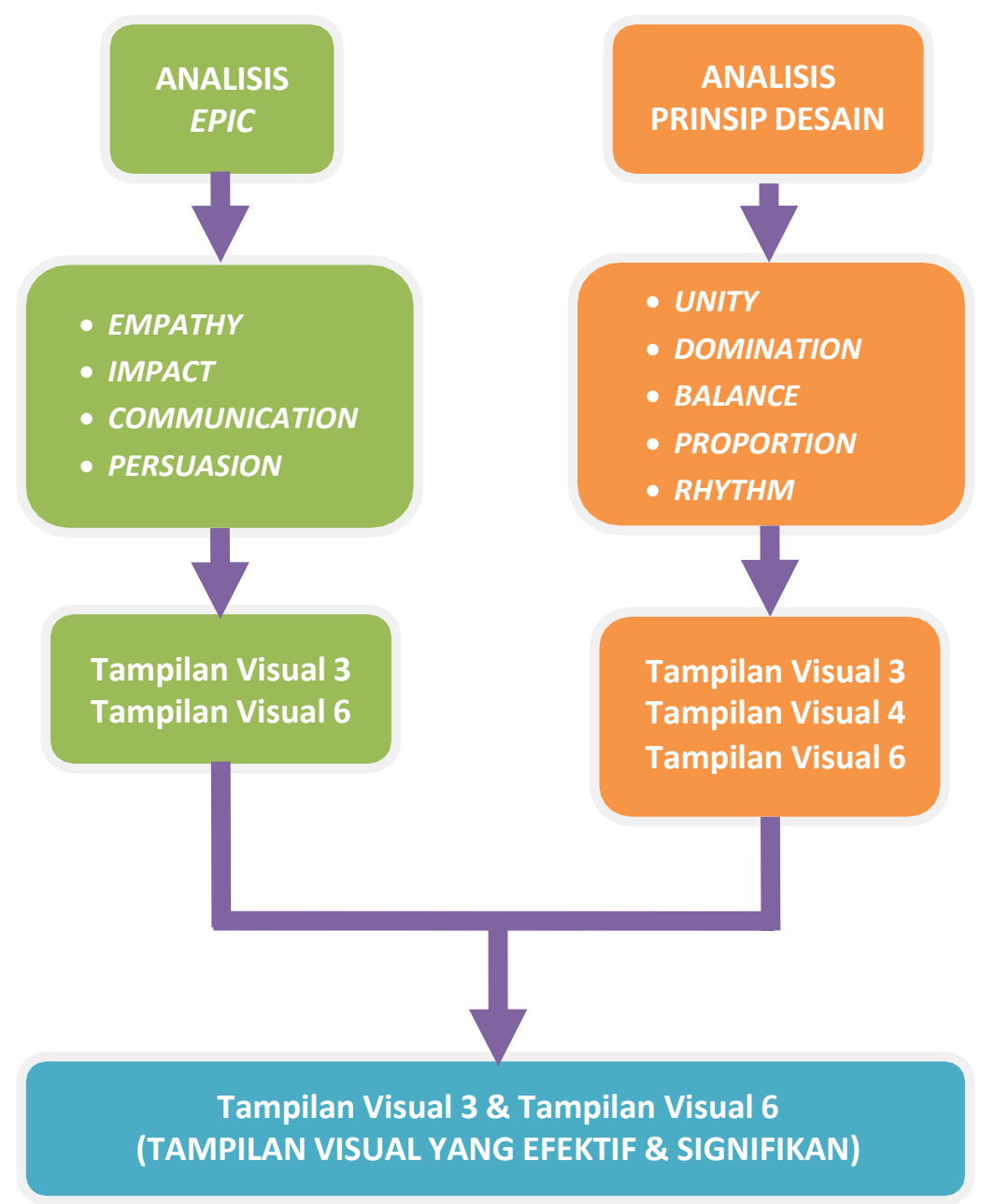

Gambar 7: Skema Temuan Analisis berdasarkan Dimensi EPIC dan Prinsip Desain 
Pemetaan urutan tampilan visual yang mempunyai nilai keefektifan dan nilai korelasi dari yang tertinggi sampai yang terendah berdasarkan hasil analisis :
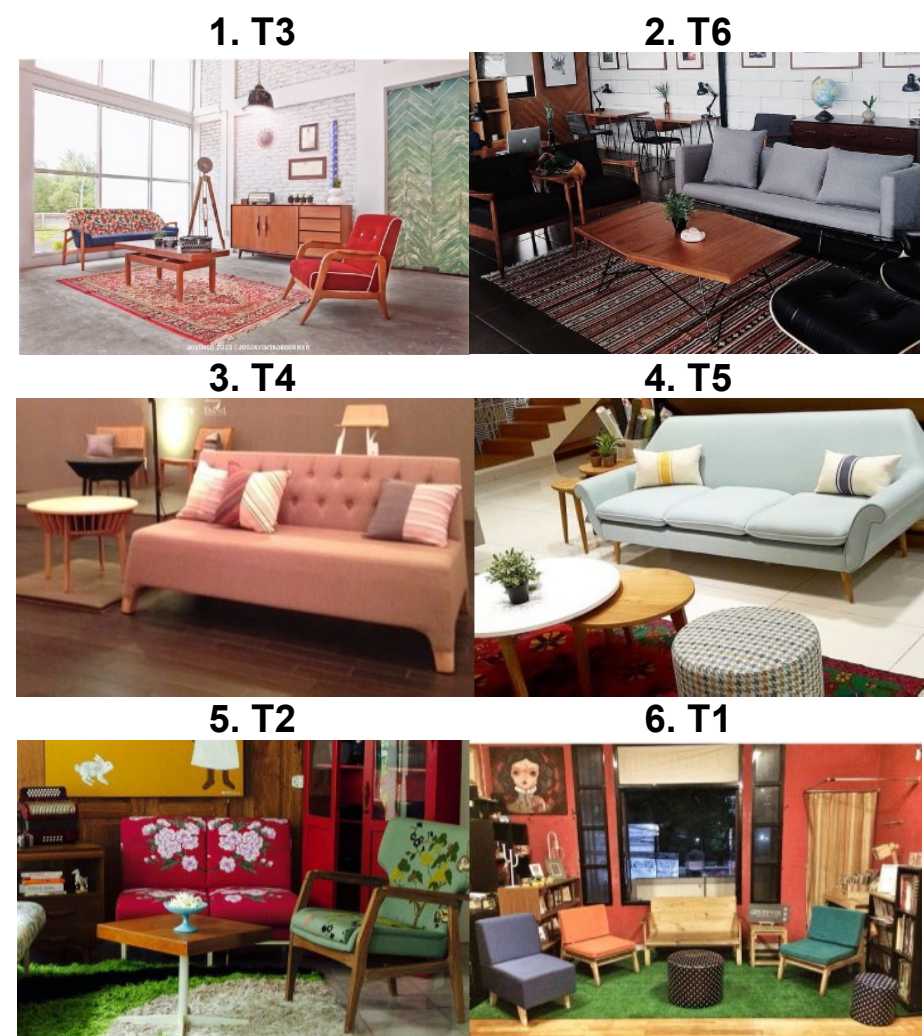

Gambar 8: Pemetaan Urutan Tampilan Visual yang Mempunyai Nilai Keefektifan dan Nilai Korelasi Tertinggi Sampai yang Terendah (sumber foto : http://instagram.com/)

Berdasarkan hasil analisis, dapat disimpulkan bahwa tampilan visual dalam bentuk foto produk furnitur yang dipasarkan melalui situs jejaring sosial Instagram berpengaruh efektif terhadap persepsi konsumen. Tingkat keefektifan tampilan visual berupa foto produk furnitur sangat dipengaruhi oleh dimensi Empathy dan dimensi Impact berdasarkan dimensi yang terdapat pada model EPIC (Empathy, Persuasion, Impact dan Communication). Dimensi Empathy melibatkan emosi dan evaluasi dari perasaan serta suasana hati konsumen terhadap tampilan visual foto produk furnitur. Sedangkan pada dimensi Impact atau dampak, melibatkan pesan dan pengetahuan produk (product knowledge) yang disampaikan melalui tampilan visual berupa foto produk furnitur kepada konsumen. Kedua dimensi tersebut, yaitu Empathy dan Impact mempunyai dominasi yang tinggi dibanding dimensi lainnya untuk dapat dipersepsi lebih baik oleh konsumen.

Untuk mendapatkan identifikasi dan pemetaan tampilan visual foto produk furnitur yang ideal untuk dipasarkan melalui situs jejaring sosial Instagram, hasil analisis pertama diperkuat dengan dimensidimensi yang terdapat pada teori prinsip desain. Dimensi yang terdapat pada teori prinsip desain yaitu; Unity, Balance, Proportion, Rhythm, dan Domination (kesatuan, keseimbangan, proporsi, irama dan dominasi). Berdasarkan hasil analisis, didapatkan bahwa dimensi pada teori prinsip desain yang dominan mempengaruhi persepsi konsumen terhadap tampilan visual berupa foto produk furnitur, adalah; dimensi Unity dan dimensi Domination. Pada dimensi Unity atau kesatuan, tampilan visual harus mempunyai beberapa unsur rupa yang mempunyai hubungan yang terkait satu sama lain dan menjadi satu kesatuan yang tidak dapat dipisahkan. Sedangkan pada dimensi Domination atau dominasi, tampilan visual harus mempunyai elemen-elemen visual sebagai penarik dan pusat perhatian (point of interest). Kedua dimensi tersebut, yaitu Unity dan Domination mempunyai nilai korelasi yang tinggi dibanding dimensi lainnya terhadap tampilan visual untuk dapat dipersepsi lebih baik oleh konsumen. 
The Effects of Visual Displays of Furniture Product Photos Through the Social Networking Site, Instagram on Consume Perception

Pengaruh Tampilan Visual Foto Produk Furnitur Melalui Situs Jejaring Sosial Instagram Terhadap Persepsi Konsumen

Pemetaan yang didapat dalam penelitian ini mengenai penggunaan tampilan visual foto produk furnitur yang ideal untuk dipasarkan melalui situs jejaring sosial Instagram, adalah sebagai berikut :

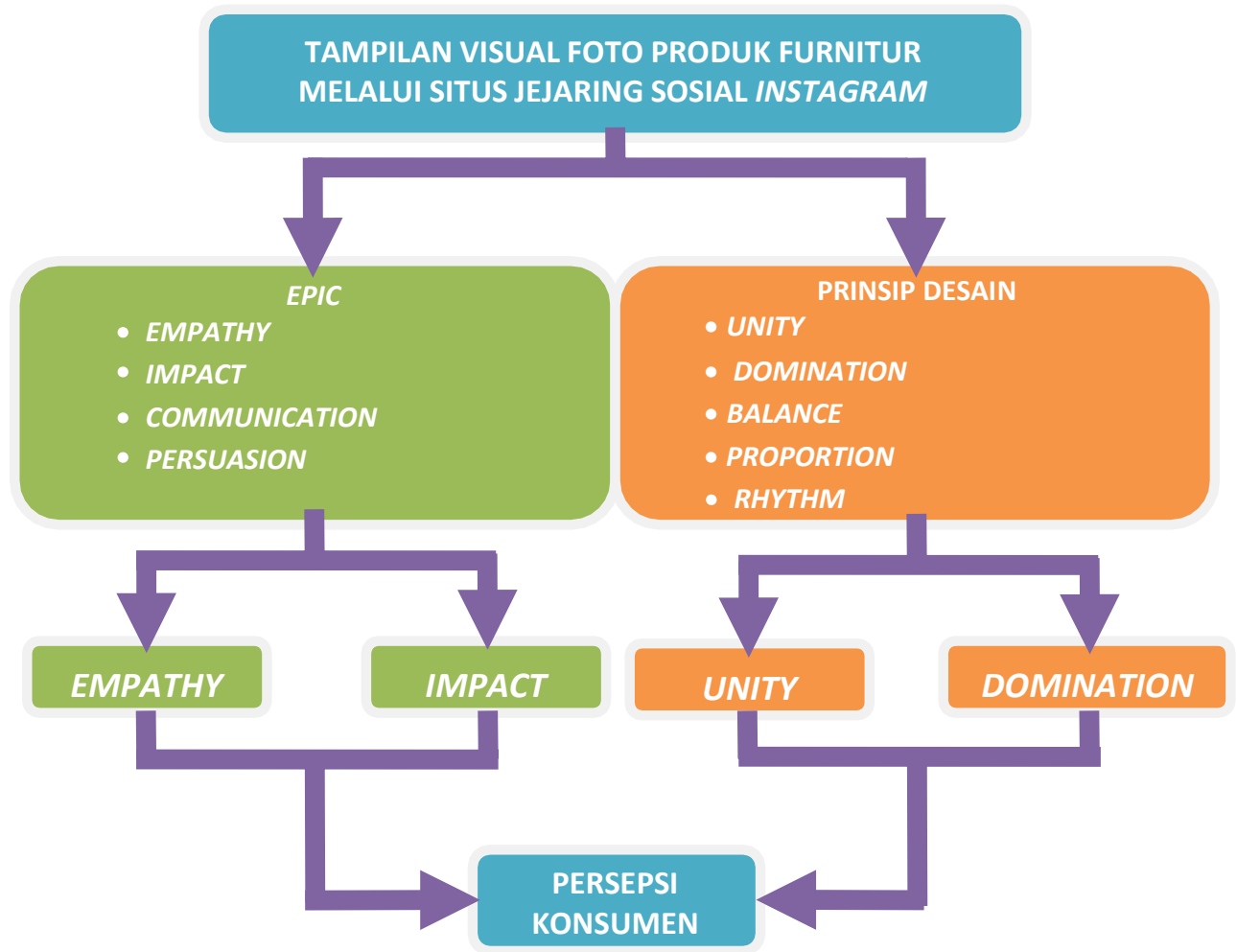

Gambar 9: Pemetaan antara Tampilan Visual Foto Produk Furnitur di Instagram dengan Persepsi Konsumen berdasarkan Dimensi EPIC dan Prinsip Desain

\section{RUJUKAN}

Abrahmov,S.L. (2008): Media Literacy : Reading and Writing Images in a Digital Age in Educating Artist for The Future: Learning at The Intersections of Art, Science, Technology, and Culture, Bristol, Intellect.

Durianto, D., Sugiarto, Widjaja, A.W., Supraktikno, H. (2003): Invasi Pasar dengan Iklan Yang Efektif. Jakarta, PT. Gramedia Pustaka.

http://instagram.com/hvnterhome

http://instagram.com/jakartavintage

http://instagram.com/jovincojogja

http://instagram.com/karsa design

http://instagram.com/kekayuan http://instagram.com/unkl347

Martono, N. (2010): Statistik Sosial: Teori dan Aplikasi Program SPSS, Cetakan Pertama, Yogyakarta, Penerbit Gaya Media.

Renaningtyas, L. (2014): Nilai Nostalgia dan Keautentikan Foto Faux Vintage dengan Filter Vintage di Instagram, Bandung, Tesis Program Studi Magister Desain Institut Teknologi Bandung.

Riyantoro, B., dan Harmoni, A. (2011): Efektivitas Iklan melalui Jejaring Sosial Sebagai Salah Satu Strategi Pemasaran Keripik Pedas Maicih dengan Menggunakan Metode EPIC, Depok, Jurnal Fakultas Ekonomi Universitas Gunadarma.

Samara, T. (2014): Design Elements: Understanding The Rules and Knowing When to Break Them, Second Edition, New York, Rockport.

Yonatia, J. (2011): Kajian Online Advertising dengan Studi Kasus: Facebook Menurut Tinjauan Ilmu $D K V$, Bandung, Tesis Program Studi Magister Desain Institut Teknologi Bandung. 
Idealogy Journal of Arts and Social Science

Vol. 3 No. 2, 2018

JOURNAL 